\title{
Budawangia and Rupicola, new and revised genera of Epacridaceae
}

\author{
Ian R. H. Telford
}

\begin{abstract}
Telford, I.R.H. (Australian National Botanic Gardens, Canberra, ACT, Australia 2601) 1992. Rupicola and Budawangia, new and revised genera of Epacridaceae. Telopea 5(1): 229-239. Rupicola Maiden \& Betche consists of four species endemic in New South Wales. Besides the type species, $R$. sprengelioides Maiden \& Betche, $\mathbf{R}$. ciliata Telford and $\mathbf{R}$. decumbens Telford are described as new and a new combination is made for $\mathbf{R}$. apiculata (Cunn.) Telford, which is transferred from Epacris. R. gnidioides Summerh. is transferred from Rupicola to the monotypic new genus Budawangia Telford as B. gnidioides (Summerh.) Telford.
\end{abstract}

\section{Introduction}

Rupicola Maiden \& Betche (1898) was established as monotypic with its only species, $R$. sprengelioides, endemic to New South Wales in the southern Blue Mountains. A second species, R. gnidioides Summerh., was described from the Southern Tablelands escarpment SW of Nowra, N.S.W., in 1927. This species has been shown to be misplaced and is here transferred from Rupicola to a new monotypic genus. More recent discoveries have yielded two new species of Rupicola described in this paper. Studies in staminal morphology have shown that a species previously included in Epacris must also be transferred to Rupicola.

Vegetative characters of Rupicola sens. str., R. gnidioides and Epacris are discussed briefly. The results of investigation of floral morphology of Australian species of tribe Epacrideae as defined by Watson (1967: 503) constitute the major part of this paper. Conclusions on systematic placement of the genera are presented.

\section{Vegetative characters}

Habit: Members of the genera Rupicola sens. str., R. gnidioides and Epacris are small multi-stemmed shrubs, usually less than one metre tall. All species of Rupicola sens. str., as well as $R$. gnidioides and several species of Epacris, are restricted to cliff-line niches and show a similarity of habit, often with decumbent or pendulous stems. Rupicola gnidioides is rhizomatous, with leafless stems spreading and proliferating through cracks in rock faces or sand on ledges. This kind of growth has not been observed in Rupicola sens. str. or Epacris.

Leaves: Rupicola sens. str., $R$. gnidioides and Epacris all exhibit the characteristic leaves of tribe Epacrideae with narrow, not sheathing, bases and longitudinal venation.

In leaf fibre pattern, in their unilacunar nodal anatomy and in homogeneous pith structure, Rupicola and Epacris belong to the 'Epacris group' of Watson (1967: 502). $R$. sprengelioides was the only member of Rupicola sens. lat. examined by Watson. 
Indumentum: Indumentum in Rupicola sens. str., $R$. gnidioides and Epacris is of simple, unicellular white hairs, typical of tribe Epacrideae. Distribution of indumentum and direction of hairs are described below under each species.

\section{Floral morphology}

The characters are discussed below with respect to the genera Rupicola sens. str. (using $R$. sprengelioides, type species of the genus), Rupicola gnidioides and Epacris.

Corolla: In R. sprengelioides, the corolla is similar to the short-tubed species of Epacris. The tube is broadly campanulate, shorter than the lobes, with the limb widely spreading. Corolla lobes are imbricate in bud. In $R$. gnidioides, corolla characters are similar.

Staminal morphology: Traditionally in generic delimitation in Epacridaceae, staminal morphology (including position of insertion of the stamens on the corolla, attachment of filaments to anthers, anthers free or cohering and anther dehiscence) remains of major significance as shown by Powell et al. (1987).

Insertion of stamens: $R$. sprengelioides has the stamens inserted at the base of the corolla tube. In $R$. gnidioides, the stamens are inserted at the mouth of the corolla tube. Epacris has the stamens inserted at the mouth of the corolla tube.

Filament characters: $R$. sprengelioides has filaments compressed and more or less equal in length to the anthers. The anthers are adnate to the filaments along their dorsal sides for most of the length of the anther. The filaments curve towards the style, with the anthers connivent but not cohering around the style. In $R$. gnidioides, the filaments are terete for most of their length, several times longer than the anthers, and curve outwards with the anthers exserted and spreading. Epacris has terete filaments shorter than the anther cells, the anthers attached dorsally at about their midpoints with the anther cells included or partly exserted from the corolla tube.

Anther dehiscence: In $R$. sprengelioides, the anther locules dehisce by a single common slit, starting apically and extending $1 / 3$ to $1 / 2$ the length of the anthers, the apices of the locules becoming curved and valve-like. In $R$. gnidioides dehiscence is longitudinal, each locule with a slit the length of the locule, the anther cell turning 'inside-out'. Epacris shows complete longitudinal anther dehiscence similar to $R$. gnidioides.

Nectary: $R$. sprengelioides possesses a discontinuous hypogynous disc of five minute swellings in the furrows at the base of the ovary. These appear to have no nectary function. In Epacris the disc is enlarged to five broad nectary scales well developed to about $1 / 3$ the length of the ovary. In $R$. gnidioides, neither nectary scales nor swellings are present.

Morphological evidence indicates $R$. gnidioides should be excluded from Rupicola. Although staminal insertion and anther dehiscence are similar to those in Epacris, other character states indicate it would be misplaced in that genus also. Rupicola (4 spp.) and Epacris (c. $40 \mathrm{spp}$.) hold consistently within their generic circumscription. Inclusion of $R$. gnidioides in either genus would destroy their natural groupings. This is borne out by studies in Epacridaceae by Powell et al. (1987). In their cladistic analyses of the family (1987: 74), Rupicola, $R$. gnidioides and the two Epacris groups constitute an unresolved trichotomy in the monophyletic tribe Epacrideae but with autapomorphic character states separating the three genera. A monotypic new genus is erected below to accomodate the anomalous species, $R$. gnidioides. 
Epacris apiculata proved to have the staminal morphology of Rupicola. A new combination is provided in Rupicola below. It is remarkable that this species has been retained in Epacris for so long as it will not key to that genus in published Floras. Bentham (1869: 241) noted its differences from other species in that genus in respect to its large anthers adnate to thick filaments.

\section{Systematic placement}

Maiden \& Betche (1898: 775) compared the anther morphology of Rupicola with the Tasmanian endemic Prionotes and corolla aestivation and vegetative characters with Epacris. Tentatively, they placed it next to Epacris in tribe Epacrideae. These studies, together with those of Watson (1967: 502) and Powell et al. (1987: 74), indicate Rupicola belongs in tribe Epacrideae adjacent to Epacris. The proposed new genus for $R$. gnidioides would occupy an intermediate systematic position.

\section{Budawangia Telford gen. nov.}

Rupicolae affinis, staminibus in orificio tubi corollae insertis, filamentis teretibus secus maximam partem longitudinis, antheris exsertis patentibus in longitudinem dehiscentibus differt.

\section{TYPE SPECIES: B. gnidioides (Summerh.) Telford}

Small rhizomatous shrubs, stems decumbent to ascending. Leaves alternate, shortly petiolate. Flowers pedicellate, solitary in upper leaf axils; pedicels bearing imbricate bracts. Bracts usually 8, lanceolate. Sepals 5, narrowly ovate, acute. Corolla shortly tubular, limb 5-lobed; lobes narrowly ovate, acute. Stamens exserted, spreading; filaments inserted at the mouth of the corolla tube, filiform for most of their length; anthers adnate to the flattened upper part of the filaments, minutely papillate, dehiscing by longitudinal slits. Ovary superior, 5-locular, 5-lobed, each lobe grooved, truncate at the apex; nectary absent; style gradually thickening towards apex, obscurely ribbed; stigma minute; ovules many per locule; placentation axile. Fruit a 5-valved capsule, dehiscing loculicidally. Seeds numerous, oblong to elliptic, reticulate.

The genus is named from the Budawang Range of the Southern Tablelands escarpment of New South Wales, to which and its associated plateaus the genus is restricted.

\section{Budawangia gnidioides (Summerh.) Telford comb. nov.}

BASIONYM: Rupicola gnidioides Summerh., Kew Bull. 8: 357 (1927)

Holotype: SOUth COAST: Ettrema River, SW of Nowra, New South Wales, F.A. Rodway s.n., Feb. 1927 (K, photograph seen).

Stems to $40 \mathrm{~cm}$ long, villous with simple white hairs. Leaves suberect to spreading; petiole c. $0.8 \mathrm{~mm}$ long; lamina narrowly lanceolate, acuminate, concave adaxially in T.S., with 3 longitudinal veins, 5-8 mm long, 1-2 mm wide, sparsely hirsute with simple white hairs on both surfaces, the margins ciliate with longer hairs. Flowers on pedicels $1.5-5 \mathrm{~mm}$ long. Sepals $2.5-3 \mathrm{~mm}$ long, $0.7-0.8 \mathrm{~mm}$ wide, glabrous or pilose outside, ciliate. Corolla white, glabrous or with a few hairs at lobe apices; tube 1-1.2 $\mathrm{mm}$ long; lobes $2.7-3 \mathrm{~mm}$ long, c. $1.5 \mathrm{~mm}$ wide. Filaments $1.7-2.3 \mathrm{~mm}$ long; anthers c. $1 \mathrm{~mm}$ long. Ovary c. $1 \mathrm{~mm}$ long, c. $1 \mathrm{~mm}$ diameter, puberulent at the summit; style 3-3.5 mm long. Capsule c. $2 \mathrm{~mm}$ long, puberulous, brown. Seeds c. $0.5 \mathrm{~mm}$ long, brown. Fig. 1. 


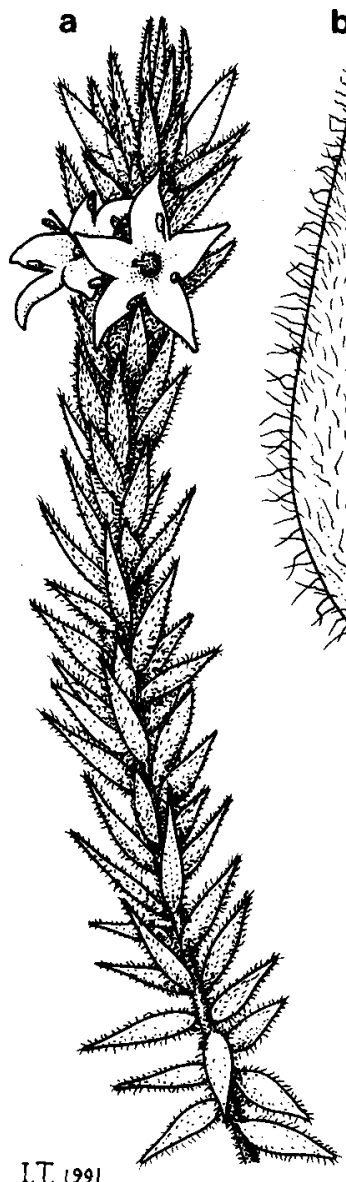

I.T. 1991 b

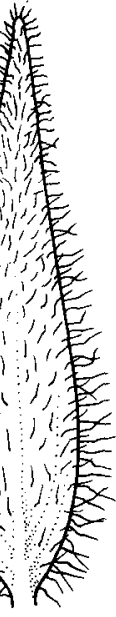

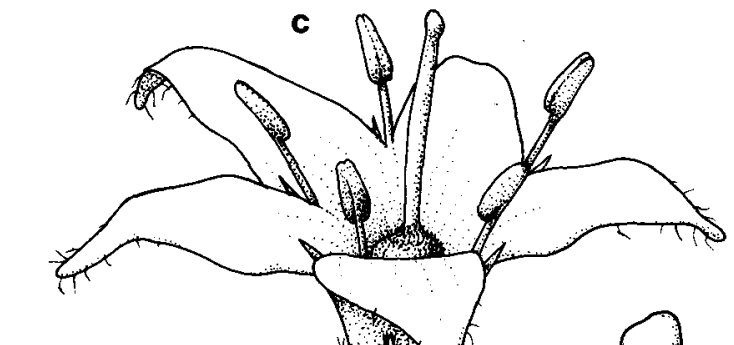

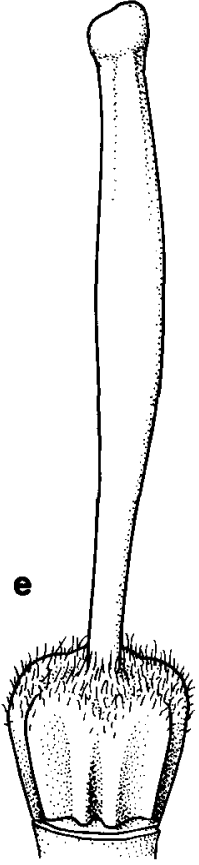

Fig. 1. Budawangia gnidioides. a, flowering stem (x 3); b, lower surface of leaf (x 10); $\mathbf{c}$, flower ( $x$ 10); d, stamens ( $x 20)$; e, gynoecium ( $x 20)$ from Telford 4125; $f$, fruit $(x 10)$; $g$, seed ( $x$ 50) from Telford 10392.

Selected specimens eXamined: New South Wales: South Coast: Myall Ck, $16 \mathrm{~km}$ NE of Nerriga, $34^{\circ} 59^{\prime} \mathrm{S} 150^{\circ} 10^{\prime} \mathrm{E}$, Telford 9606 (CBG, AD, BRI, MEL, NSW); Northern Budawang Range, The

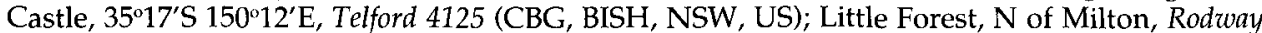
2541 (NSW). Southern Tablelands: Upper Corang River, c. 10 miles [16 km] SE of Nerriga,

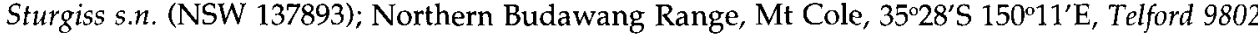
(CBG, $\mathrm{HO}, \mathrm{K}$ ).

DistRIBUTION: Budawangia gnidioides is restricted to the northern Budawang Range and associated sandstone plateau escarpments of the South Coast and Southern Tableland districts of New South Wales. Fig. 2.

ECOLOGY: Budawangia gnidioides occurs only in cliff-line niches, growing in cracks in sandstone rock faces or on sandy ledges, usually beneath cliff overhangs and adjacent to open forest or heathland. Associated species include Baeckea linifolia Rudge, Gleichenia rupestris $\mathrm{R}$. Br. and Todea barbara $\mathrm{L}$. 


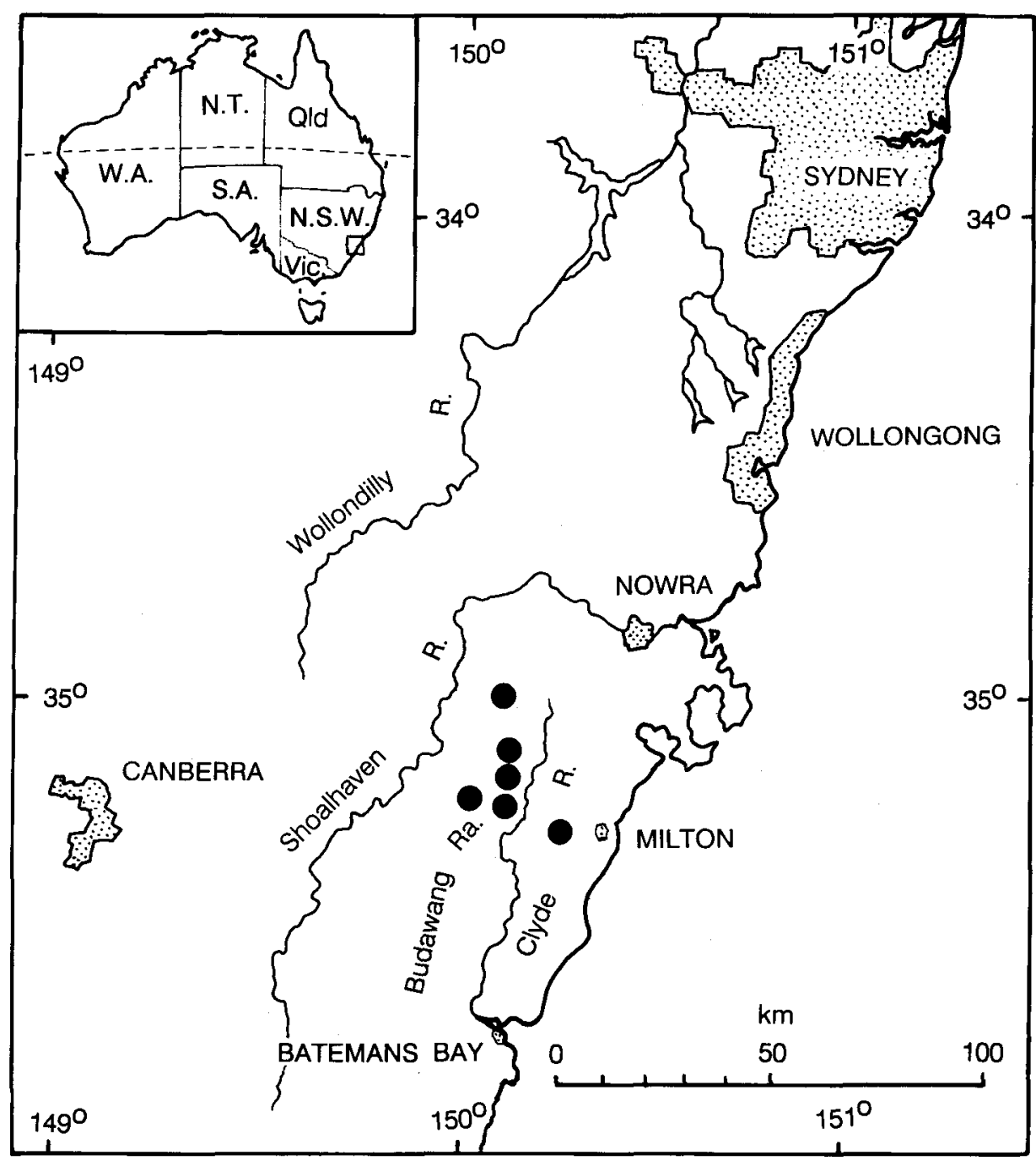

Fig. 2. Distribution of Budawangia gnidioides.

FLOWERING PERIOD: September to December.

CONSERVATION: The narrow range of the species, mostly within Morton National Park, gives the species a 2VC-t coding, conserved but vulnerable, following Briggs \& Leigh (1988: 37) as Rupicola gnidioides. Possible threats are from wildfires and bush-walkers. Disturbance of some populations, including uprooting of plants, has been observed in camping caves. 


\section{Rupicola Maiden $\mathcal{E}$ Betche}

Maiden \& Betche (1898: 775, t. 28)

\section{TYPE SPECIES: $R$. sprengelioides Maiden \& Betche}

Shrubs with ascending or decumbent stems, branching alternate or irregularly verticillate; branchlets terete, pilose with simple hairs, usually marked by persistent leaf scars. Leaves alternate, shortly petiolate or subsessile, the lamina ovate, narrowly ovate or narrowly elliptic, glabrous, puberulous or pilose with simple hairs. Flowers solitary in the upper axils, the pedicels covered by imbricate bracts increasing in size towards the flower; bracts narrowly ovate, narrowly acute, the upper somewhat smaller than the sepals. Sepals 5, narrowly ovate, acute, ciliolate. Corolla shortly tubular, glabrous, white; tube broadly campanulate; limb 5-lobed, widely spreading; lobes ovate, acute, longer than the tube, imbricate in the bud. Stamens hypogynous, inserted at the base of the corolla tube; filaments compressed, as long as or shorter than anther locules; anthers papillate, adnate to filaments, connivent around the style; locules 2-celled, dehiscing by a shared single slit from the apex to $1 / 3$ to $1 / 2$ length of locules. Hypogynous disc discontinuous, of 5 minute non-nectiferous scales, 1 at the base of each ovary furrow. Ovary superior, shortly cylindrical to oblate, 5-lobed, 5-locular; placentation axile; ovules numerous. Style short, terete to obscurely ribbed, inserted in a depression in the summit of the ovary; stigma minute. Fruit a 5-valved capsule, dehiscing loculicidally. Seeds many, elliptic to reniform, pale brown, with reticulate ornamentation.

A genus of 4 species endemic to the Central Tablelands and adjacent western parts of the Central Coast of New South Wales.

\section{Key to the species}

1 Leaves ovate, cordate, the acuminate apices thickened

2. R. apiculata

$1^{*}$ Leaves narrowly elliptic to elliptic, occasionally narrowly ovate, the apices not thickened

2 Corolla 13-17 mm diam.; ovary pilose

4. R. decumbens

2* Corolla 8-12 mm diam.; ovary glabrous

3 Leaf lamina pilose, ciliate

3. R. ciliata

$3 *$ Leaf lamina usually glabrous

1. R. sprengelioides

\section{Rupicola sprengelioides Maiden \& Betche (1898: 774).}

Holotype: New South WAles: Central Tablelands: Southern edge of Kings Tableland, Blue Mountains, J.H. Maiden $\mathcal{E}$ W. Forsyth, Sept 1898 (NSW).

Collection date is misquoted as Oct 1898, in the protologue.

Erect shrub to $2 \mathrm{~m}$; branchlets puberulent to villous with antrorse white hairs to 0.5 $\mathrm{mm}$ long, the hairs becoming more spreading with age. Leaves suberect to spreading; petioles c. $1 \mathrm{~mm}$ long, puberulent; lamina narrow-elliptic with an obtuse rigid apex, adaxially shallowly concave in T.S., venation obscure with 5 longitudinal veins, (10-)20-32 mm long, 1.5-3 mm wide, usually glabrous, minutely ciliolate, sometimes 
puberulent at base on underside. Flowers on puberulent pedicels 4-9 mm long; bracts 0.5-4 mm long, ciliolate. Sepals 3-7 mm long, ciliolate. Corolla 8-10 mm diameter, glabrous, white; tube 1.5-2 mm long; lobes (3-)4-6 mm long. Stamens with filaments c. $1 \mathrm{~mm}$ long; anthers c. $2 \mathrm{~mm}$ long. Ovary c. $1.5 \mathrm{~mm}$ long, glabrous. Style $2-4 \mathrm{~mm}$ long. Capsule c. $2 \mathrm{~mm}$ diameter, glabrous.

DistriBuTron: The species is apparently restricted to the cliff-lines of the Burragorang Valley of the Central Tablelands where it has been recorded from McMahons and Burragorang Lookouts and the adjacent catchment of Erskine Creek at Nepean Lookout. Fig. 4.

ECOLOGY: R. sprengelioides inhabits rocky cliff top niches, growing in sand on sandstone in open forest at altitudes of $450-650 \mathrm{~m}$. Associated species include Allocasuarina littoralis (Salisb.) L. Johnson, Banksia serrata L. f. and Platysace lanceolata (Labill.) C. Norman.

FLOWERING PERIOD: October to November, sometimes with an autumn flowering in April.

ConSERVATION STATUS: 2RC-t, following Leigh \& Briggs (1988: 38). The species is known from only three populations, two of which lie within Blue Mountains National Park.

Selected specimens examined: New South Wales: Central Tablelands: McMahons Lookout, Kings Tableland, Bowden, Jan 1968 (NSW 137887); Burragorang Lookout, 20 km NW of Picton, Telford 7219, 27 Nov 1978 (CBG, BISH, HO, K, MEL, NSW, US).

\section{Rupicola apiculata (Cunn.) Telford comb. nov.}

BAsIONYM: Epacris apiculata Cunn. in Field, Geogr. Mem. New South Wales: 340 (1825)

TYPE CITATION: 'Ravines, Kings Table Land'.

Apparently three gatherings of Allan Cunningham in 1822 are held in BM and $\mathrm{K}$ (photographs seen). The BM sheet is annotated 'Epacris apiculata. Cunningham 1822' in Cunningham's handwriting. The K sheet bears three elements, one labelled '8. Epacris apiculata. A very rare plant discovered in rocky ravines in the vic[initly of the Kings Tableland, Blue Mtns, Oct. 1822', the other two 'Epacris apiculata. Rare on moist mossy rocks, ravines, B[lue] M[ountains]' in Cunningham's handwriting. These are best regarded as syntypes. The tagged flowering twig on the $\mathrm{K}$ sheet bearing the Herbarium Hookerianum stamp is the best specimen.

LeCTOTYPE (here chosen): New SOUtH WALES: Central Tablelands: Rare on moist mossy rocks, ravines, B[lue] M[ountains], A. Cunningham, 1822 (K, photograph seen).

Decumbent to erect shrub; stems to $1 \mathrm{~m}$ long; branchlets puberulent with antrorse to spreading white hairs. Leaves spreading to reflexed, subsessile; lamina ovate, cordate, adaxially concave in T.S., venation obscure with 5 longitudinal nerves, 3-10(12) $\mathrm{mm}$ long, 2.5-7 mm wide, acuminate with a rigid thickened apex, glabrous. Flowers on glabrous pedicels $1.5-2 \mathrm{~mm}$ long; bracts $0.7-2.5 \mathrm{~mm}$ long, glabrous. Sepals 2-2.5(-4) $\mathrm{mm}$ long, glabrous. Corolla 7-9 $\mathrm{mm}$ diameter, glabrous, white; tube 1$3.5 \mathrm{~mm}$ long; lobes 3-3.5(-5) mm long. Stamens with filaments c. $0.75 \mathrm{~mm}$ long; anthers 1.5-2 mm long. Ovary c. $1 \mathrm{~mm}$ long, glabrous. Style 3.5-5(-6) mm long. Capsule c. $1.5 \mathrm{~mm}$ diameter, glabrous. Fig. 3.

Distribution: The species is restricted to the Central Tablelands in the higher Blue Mountains between Blackheath and Leura. Fig. 4. 
ECOLOGY: R. apiculata inhabits cliff-line niches on moist sandstone shelves beneath rock overhangs adjacent to heathland or open forest at altitudes of $850-1000 \mathrm{~m}$. Associated species include Epacris reclinata Cunn. ex Benth., Sprengelia monticola (Cunn. ex DC.) Druce and Glichenia rupestris R.Br.

FLOWERING PERIOD: September to November, sometimes with an autumn flowering in April.

CONSERVATION STATUs: 2RCa, following Briggs \& Leigh (1988: 36) as Epacris apiculata. Several populations lie within Blue Mountains National Park.
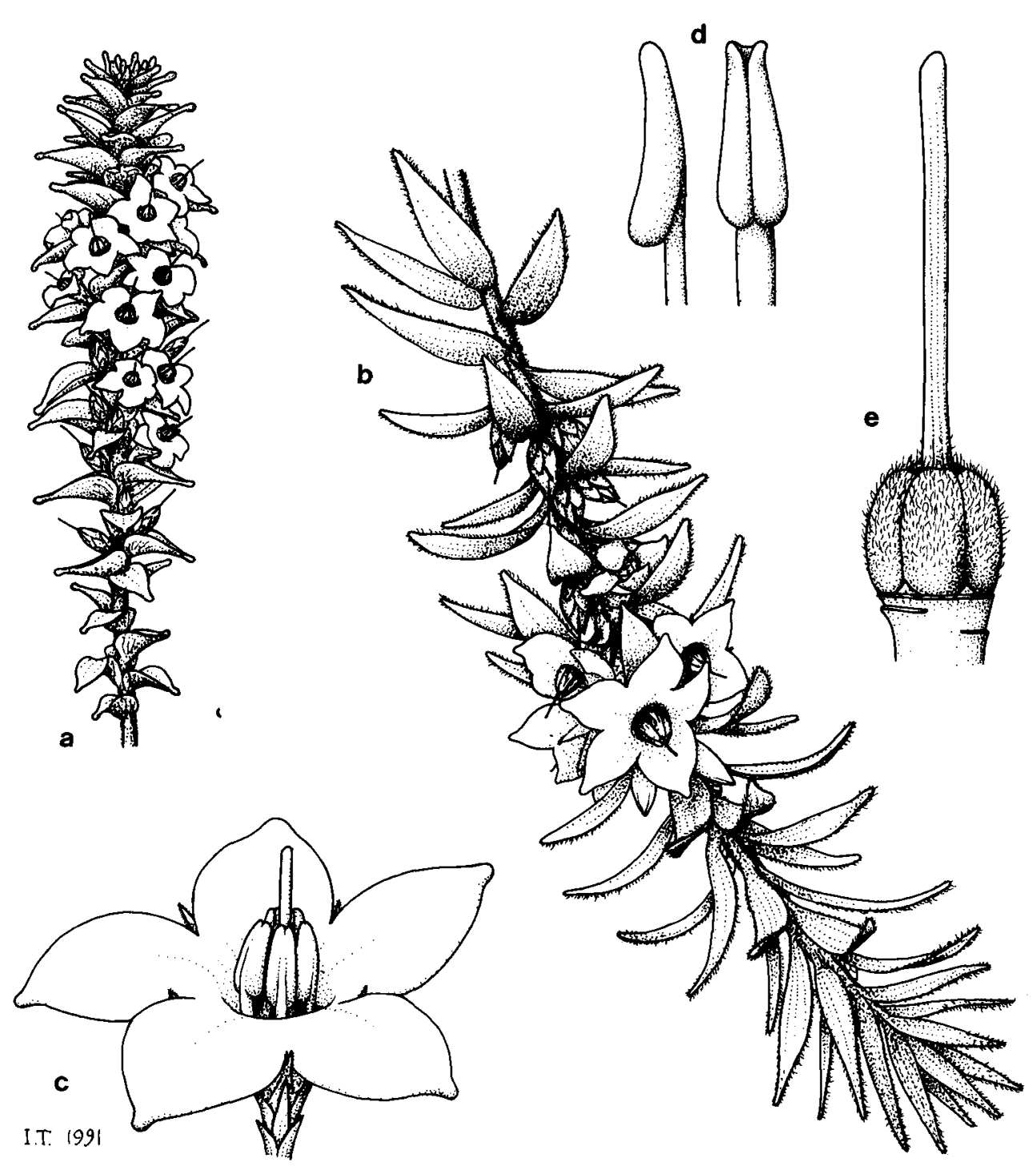

Fig. 3. Rupicola spp. R. apiculata. a, flowering stem (x 2) from Telford 7229. R. decumbens. b, flowering stem (x 1.5) from Telford 7227; c, flower (x 5); d, stamens (x 10); e, gynoecium (x 10) from holotype. 
Selected specimens examined: Central Tablelands: Centennial Glen, $1 \mathrm{~km} \mathrm{~W}$ of Blackheath, Telford 7229, 9 Dec 1978 (CBG, BISH, HO, K, MEL, NSW, US); Leura Falls, Hamilton, Nov 1913 (NSW 249664); Lake Medlow, c. 2 miles [3 km] SE of Blackheath, Constable 8 Jul 1959 (NSW 249694,); Minni Ha Ha Falls, Katoomba, Evans, 7 Nov 1961 (NSW), Wentworth Falls, Constable NSW 38000, 4 Oct 1948 (NSW)

\section{Rupicola ciliata Telford sp. nov.}

$R$. sprengelioidi affinis, habitu decumbente vel effuso et foliis plerumque latioribus lamina pubescente marginibus pilis longioribus ciliatis differt.

Holotype: New SOUTH WALES: Central Coast: Wheeny Ck catchment, $4 \mathrm{~km}$ from Kurrajong Heights towards Bilpin along Bells Line of Road, 33 31'S 150'37'E, I.R. Telford 10824 \& D.H. Moffatt, 13 November 1989 (CBG; isotypes BISH, HO, K, MEL, NSW).

Pendulous, decumbent to spreading shrub; stems to $50 \mathrm{~cm}$ long; branchlets pubescent with spreading more or less crisped white hairs. Leaves suberect to spreading on erect stems, becoming reflexed on pendulous stems; petioles $0.5-1 \mathrm{~mm}$ long, puberulent; lamina narrow-elliptic to narrowly ovate, bluntly acute, adaxially shallowly concave in T.S., venation obscure with 5 longitudinal nerves, 3 extending to the lamina apex, 6-13(-16) $\mathrm{mm}$ long, 1.5-4 $\mathrm{mm}$ wide, sparsely white puberulent on both surfaces, the margins ciliate with longer white hairs. Flowers on sparsely puberulent pedicels 2-8 mm long; bracteoles $0.7-3 \mathrm{~mm}$ long, ciliolate. Sepals 3-4 mm long, ciliolate. Corolla 10-13 mm diameter, glabrous, white; tube 2-3 mm long; lobes 3.5-5 $\mathrm{mm}$ long. Stamens with filaments 1-2 mm long; anthers c. $2 \mathrm{~mm}$ long. Ovary oblate, c. $1 \mathrm{~mm}$ long, glabrous. Style c. $3 \mathrm{~mm}$ long, glabrous. Capsule c. $2.5 \mathrm{~mm}$ diameter, glabrous.

The specific epithet refers to the leaf margins.

Distribution: The species is apparently restricted to the lower north-eastern Blue Mountains in the Central Tablelands and the adjacent north-western part of the Central Coast. Fig. 4.

ECOLOGY: Rupicola ciliata inhabits cliff-lines of ridges and gorges, in crevices and on ledges of sandstone and conglomerate in open forest. Associated species include Alania endlicheri Kunth. and Gleichenia rupestris $\mathrm{R}$. Br.

FLOWERING PERIOD: October to December.

CONSERVATION STATUS: 2RCt, following the criteria in Briggs \& Leigh (1988). All known populations lie within Blue Mountains and Wollemi National Parks.

Notes: On herbarium sheets, this species superficially resembles $R$. sprengelioides but that species is a more robust erect shrub, whereas $R$. ciliata has pendulous to spreading stems.

Specimens eXAmined: New South Wales: Central Coast: First fireplace W of Kurrajong Heights on Bells Line of Road,14 Oct 1987, Hind 5368 (NSW); 'Froth and Bubble' Ck, Bungleboori Ck area, $\mathrm{N}$ bank tributary of Wollangambe R., $\mathrm{N}$ of Mt Wilson, 33 $22^{\prime} \mathrm{S} 150^{\circ} 20^{\prime} \mathrm{E}$, Gibson 14, $27 \mathrm{Dec} 1988$

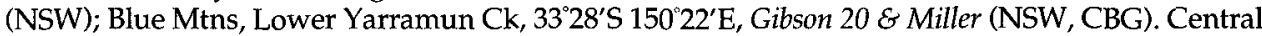
Tablelands: Bilpin, $33^{\circ} 30^{\prime} \mathrm{S} 150^{\circ} 32^{\prime} \mathrm{E}$, Constable NSW 48901 (NSW, CBG).

\section{Rupicola decumbens Telford sp. nov.}

$R$. ciliatae affinis, foliis plerumque majoribus, floribus in pedicellis brevioribus (1-2 $\mathrm{mm}$ longis), corollae majoribus (13-17 mm diam.) et ovariis pubescentibus differt.

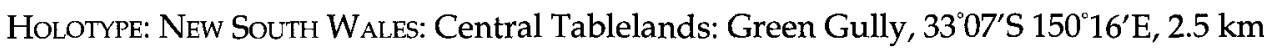
SW of Glen Davis, I.R. Telford 5019 \& M.D. Crisp, 25 Oct 1976 (CBG; isotypes K, NSW). 


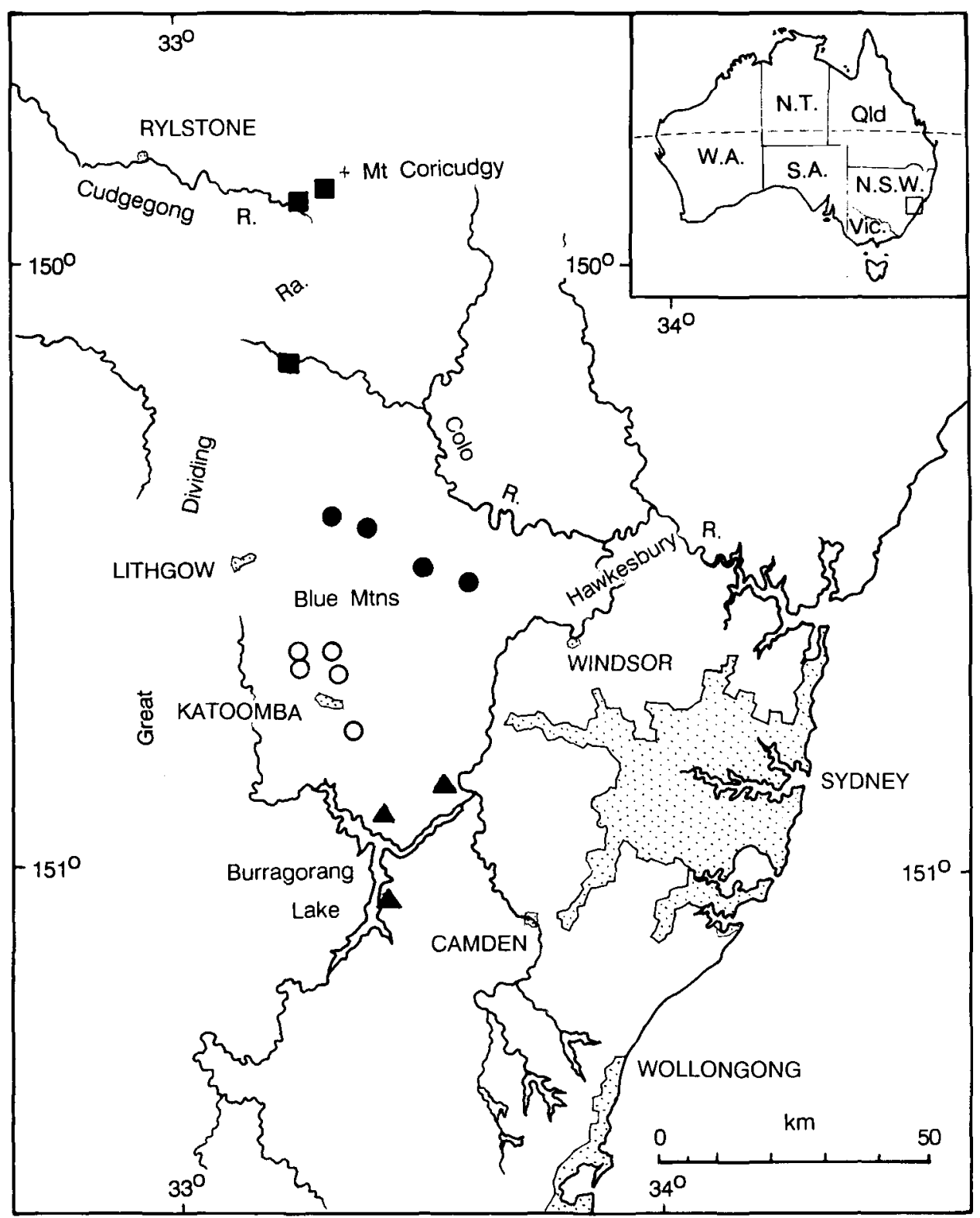

Fig. 4. Distribution of Rupicola spp. $(\Delta) R$ sprengelioides, $(O) R$. apiculata, $(\bullet) R$. ciliata and (荞 R. decumbens. 
Decumbent shrub; stems to $1 \mathrm{~m}$ long; branchlets pubescent with crisped and straight white hairs $0.5-1 \mathrm{~mm}$ long. Leaves spreading to reflexed; petioles c. $1 \mathrm{~mm}$ long, puberulent; lamina narrowly elliptic to narrowly ovate,bluntly acute, adaxially shallowly concave in T.S., venation obscure with 5 longitudinal nerves, (7-)10-18 mm long, 3-4.5 mm wide, sparsely white pubescent on upper surface, more densely so beneath, ciliate around the margins with straight white hairs to $1 \mathrm{~mm}$ long. Flowers on puberulent pedicels 1-2 $\mathrm{mm}$ long; bracts 1-7 mm long, ciliolate. Sepals 5-7 mm long, ciliolate. Corolla 13-17 mm diameter, glabrous, white; tube 1-1.5 mm long; lobes 7-8 mm long. Stamens with filaments c. $1.5 \mathrm{~mm}$ long; anthers $2.5-5 \mathrm{~mm}$ long. Ovary 1.5-2 $\mathrm{mm}$ long, pubescent. Style $4.5-7 \mathrm{~mm}$ long, sparsely pubescent. Capsule c. $4 \mathrm{~mm}$ diameter, pubescent. Fig. 3 .

The specific epithet refers to the habit of the plant.

Distribution: The species is restricted to the Central Tablelands in the northern Blue Mountains and the adjacent Mount Coricudgy area E of Rylstone. Fig. 4.

Ecologr: $R$. decumbens inhabits cliff base niches on sandstone ledges and in crevices adjacent to open forest at altitudes of $500-950 \mathrm{~m}$. Associated species include Leptospermum rupicola J. Thompson, Gleichenia rupestris $\mathrm{R}$. Br. and Epacris reclinata Benth.

FLOWERING PERIOD: November to December.

CONSERvatron STATUs: 2RC-, following the criteria of Briggs \& Leigh (1988: 36) where it is listed as Rupicola sp. 1 (Glen Davis). Several populations lie within Wollemi National Park.

Selected specimens eXamined: New South Wales: Central Tablelands: c. 2 miles [3 km] NNW of Mt Coricudgy, McGillivray 117 \& Rodd, 25 Apr 1965 (NSW); head of Cudgegong River, Whaite 961, 15 Aug 1951 (NSW); Kelgoola Picnic Area, Cudgegong River, Powell 2974, 25 Jul 1987 (NSW, CBG, HO); 2 km SSW of Glen Davis, Coveny 9449 \& Telford, 18 May 1977 (NSW, CBG).

\section{Acknowledgements}

I thank the Director and staff, Royal Botanic Gardens, Sydney, for the loan of specimens. Dr Jocelyn Powell of the National Herbarium of N.S.W. of that institution provided valuable encouragement and discussion. Dr Ahmad Abid Munir, while Botanical Liaison Officer at Kew, arranged for the photography of type specimens held at $\mathrm{K}$ and BM. Dr Michael Crisp of the Division of Botany and Zoology, Australian National University, kindly wrote the Latin diagnoses.

\section{References}

Bentham, G. (1869) Flora Australiensis vol. 4.

Briggs, J.D. \& Leigh, J.H. (1988) Rare or Threatened Australian Plants. Australian National Parks \& Wildlife Service Special Publication 14.

Field, Barron (1825) Geographical Memoirs of New South Wales.

Maiden, J. H. \& Betche E., (1898) Notes from the Botanic Garden, Sydney 3. Proc. Linn. Soc. New South Wales 23: 772-779.

Powell, J. M., Chapman, A.R. \& Doust, A.N.L. (1987) Classification and generic status in Epacridaceae - a preliminary analysis. Austral. Syst. Bot. Soc. Newsletter 53: 70-78.

Summerhayes, V. S. (1927) XXXIX, - Decades Kewenses - Plantarum novarum in herbario horti regii conservatarum. Decas CXVIII. Kew Bull. for 1927: 356-363.

Watson, L. (1967) Taxonomic implications of a comparative anatomical study of Epacridaceae. New Phytol. 66: 495-504. 